\section{Digestive Surgery}

Dig Surg 2000;17:1

\section{Editorial}

DIGESTIVE SURGERY welcomes the Dutch Society of Gastrointestinal Surgery (NVGIC)!

Our first issue of Digestive Surgery 2000 features major advances into the future.

First of all, 400 colleagues from the Dutch Society of Gastrointestinal Surgery have joined the European Digestive Surgery and our journal Digestive Surgery, and this brings considerable new input for both. We cordially welcome our Dutch colleagues particularly because their high-quality standards of surgical care and research activities are well known and constitute a major argument for this joint venture. We are looking forward to a very fruitful cooperation.

Negotiations between two further major national GI surgical societies and Digestive Surgery are under way at the moment and we foresee two further joint ventures being contracted in the year 2000. These prospects are really good news for the editorial team, as well as all our subscribers because these events will enable us to meet one of our major goals: namely to become the leading international journal for digestive surgery.

This January issue features the summary articles of the ISDS/EDS Postgraduate Course that was held 3 months ago during the UEGW in Rome. Thanks to the very speditive action of our editorial team, it was possible to have this published already, bringing the most recent GI oncology results to our readers.

From 2000 on we adopt the policy of publishing invited commentaries on original articles to adequately balance the content of these articles with the opinions of surgical leaders. This should make it easier for our readers to accept new surgical strategies.

Also in 2000 we will start a new 'historic section' to remind us of the real progress accomplished by GI surgeons in the past. These articles will feature the surgical invention as well as the person who achieved it.

Quality first is our goal also in 2000 and we encourage all our readers to submit their first-class articles to our journal. Having restructured the review process, we can assure rapid publication.

M.W. Büchler

E.H. Farthmann

\section{KARGER}

Fax + 41613061234

E-Mail karger@karger.ch

www. karger.com
(C) 2000 S. Karger AG, Basel

0253-4886/00/0171-0001\$17.50/0

Accessible online at:

www.karger.com/journals/dsu 